\title{
EFFECT OF GARLIC AS A FEED ADDITIVE ON REPRODUCTIVE PERFORMANCE AND BODY WEIGHT OF NILE TILAPIA BROODSTOCK
}

\author{
Ahmed Abd Alla Abd El-Rahman Ali \\ Central Laboratory for Aquaculture Research, Agricultural Research \\ Center, Ministry of Agriculture, Egypt
}

\section{ABSTRACT:}

This study was conducted at commercial hatchery at Kafr ElSheikh Governorate and the analytical studies were conducted at Anim. Prod. Laboratory, Faculty of Agriculture Fayoum University to evaluate the effect of three Garlic levels $(0.0,0.5$ and $1.0 \%)$ in Nile tilapia diets on their reproductive performance and their body weight.

One year old Nile tilapia (Oreochromis niloticus) with average weight of $240 \mathrm{~g} \pm 3.16$ were stocked for spawning into six hapas at a density of 200 fish (150 female and 50 male) per hapa, two hapas/treatment. Hapas were fixed in earthen pond. Fish fed the tested diets at a rate of $0.5 \%$ from their total biomass. Water quality parameters were measured. Production of seed (i.e., eggs and fry production) were compared with the tested diets. The results revealed that spawned females/wk, fecundity as the number of eggs produced per female and fry production per fish were significantly affected by dietary Garlic level. The highest values were obtained with the diets contained $0.5 \%$ or $1.0 \%$ Garlic levels. Feed conversion as a feed required to produce 1000 fry was the best with the Garlic supplementation diets.

It could be concluded that tilapia diets supplemented with Garlic had a positive effect on their reproductive and feed utilization. Comparisons between tested levels may suggest the use of $0.5 \%$ Garlic level.

Key words: Nile tilapia, reproductive performance, body weight and Garlic

\section{INTRODUCTION:}

Low egg production per spawning and lack of spawning synchrony among tilapia females constrains the management of mass seed production (Jalabert and Zohar, 1982; Little et al., 1993) and this impacts upon the tilapia industry as a whole. As large numbers of parental stock are required in order to meet the demand for seed (Mires, 1982; Little et al., 1997), a hatchery operator has to maximize seed output by exploiting the reproductive potential of his/her broodstock (Springate and Bromage, 1984; Macintosh and Little, 1995). Feed additives have a physiological and economic significance. They are added to the feed of fish to improve growth or reproductive performance and efficient feed utilization or control sexual development (Abd El-Maksoud, et $a l, 1998$ a,b; 1999).

Garlic is commonly cultivated in Egypt as one of the important crops of annual plants, used widely in daily food preparation. Beside the culinary use of the plant, it is reputed to have wide medicinal applications (El-Emary, 1993).

Addition of garlic to the diet improving growth performance of poultry (El-Nahla, 1983, E1-Nawawy, 1991, Horton et al., 1991 and Day and Samanto, 1993)

Fayoum J. Agric. Res. \& Dev., Vol.24, No.2, July, 2010 
EFFECT OF GARLIC AS A FEED ADDITIVE ON REPRODUCTIVE.. 209

El-Emary (1993) reported that chickens lay more eggs when Garlic is mixed with their food.

Regarding fish, Ali (2001) studied the effect of Biogen (commercial product, its main ingredient are allicin, germanium and high unit hydrolytic enzyme) as a feed additive on growth performance of Nile tilapia fingerlings. Three dietary levels tested $(0.0,0.5$ and $1.0 \mathrm{~kg} / \mathrm{ton})$ of Biogen and found that increasing Biogen supplementation positively affected $(\mathrm{P} \leq 0.05)$ the Nile tilapia biomass at harvesting, feed utilization and economic efficiency.

The present work was conducted to evaluate Garlic as a feed additive on reproductive performance and body weight of Nile tilapia broodstock

\section{MATERIALS AND METHODS}

This trial was conducted from $21 / 6$ to $16 / 8 / 2009$ to evaluate the effect of three Garlic levels (0.0 (control), 0.5 and $1.0 \%$ from the total diet) in Nile tilapia pelleted $(2 \mathrm{~mm})$ diets on their fecundity, hatchability, fry production and their body weight.

One year old Nile tilapia (Oreochromis niloticus) belonging to the year 2008 generation with an average weight of $240.5 \mathrm{~g} \pm 3.44$ were stocked for spawning into six hapas (each of $7 \mathrm{~m}$ length $\times 5 \mathrm{~m}$ width $\times 1.2 \mathrm{~m}$ height), two per each treatment. As each treatment was represented by 2 hapas, the distance between treatments 1 and 2, 2 and 3 was $10 \mathrm{~m}$ each. Hapas were fixed in an earthen pond (one feddan area $\times 1 \mathrm{~m}$ depth) with water level of $90 \mathrm{~cm}$ where $1 / 3$ of the water level was exchanged with fresh water every 3 days. Such pond was supplied with defused aeration.

Table (1). Formulation and proximate composition of the tested diets.

\begin{tabular}{||l|c|c|c|}
\hline \multirow{2}{*}{ Items } & \multicolumn{3}{|c|}{ Garlic level, \% } \\
\cline { 2 - 4 } & $\mathbf{0 . 0}$ & $\mathbf{0 . 5}$ & $\mathbf{1 . 0}$ \\
\hline Ingredients, \% & 30.00 & 30.00 & 30.00 \\
Fish meal & 15.00 & 15.00 & 15.00 \\
Soybean meal & 21.00 & 21.00 & 21.00 \\
Rice bran & 16.00 & 16.00 & 16.00 \\
Wheat bran & 14.00 & 13.50 & 13.00 \\
Yellow corn & 2.75 & 2.75 & 2.75 \\
Molasses & 1.00 & 1.00 & 1.00 \\
Dicalcium phosphate & 0.25 & 0.25 & 0.25 \\
Vit \& Min. premix & 0.00 & 0.50 & 1.00 \\
Garlic & 100 & 100 & 100 \\
Total & 89.59 & 89.32 & 89.05 \\
Proximate composition , \% (DM basis) & 34.72 & 34.68 \\
\hline Dry matter, DM. & 34.76 & 6.90 & 6.88 \\
Crude protein, CP. & 6.91 & 5.68 & 5.68 \\
Crude fat, EE. & 5.69 & 43.28 & 43.33 \\
Crude fiber, CF. & 43.22 & 9.42 & 9.43 \\
NFE ${ }^{1}$ & 9.42 & 4.543 & 4.542 \\
Ash & 4.545 & 76.42 & 76.35 \\
GE, Kcal/g * & 76.48 & 18.27 & 18.26 \\
CP/GE, mg/kcal & 18.29 & \multicolumn{3}{|c|}{} \\
CP/GE, mg/KJ
\end{tabular}

1, Calculated by difference.

* Calculated according to Omar, 1984.

Fayoum J. Agric. Res. \& Dev., Vol.24, No.2, July, 2010 
Fish were stocked at a density of 200 fish (150 female and 50 male) per hapa. Diets of similar CP (34.72\% \pm 0.019$)$ and GE (4.543 kcal /g \pm 0.001$)$ were arranged to contain $0.0,0.5$ and $1.0 \%$ Garlic levels from the total diets forming 3 dietary treatments. The formulation and proximate composition of the tested diets are shown in Table (1). Fish were fed the tested diets at a rate of $0.5 \%$ from their total biomass twice daily at $9 \mathrm{~h}$. and $15 \mathrm{~h}$. Fish body mass was determined at two week intervals and feeding rate of the tested diets was adjusted through the two week intervals weighing for the next period.

Production of seed (i.e., eggs and fry production) and rate of spawning were compared with the tested diets. Female fish were checked for eggs every week. Early in the morning, females carrying the eggs were taken from the hapa and returned after taking out the eggs. Eggs were taken to hatchery laboratory, then washed by potassium permengenate solution to prevent bacterial and fungal infection. All eggs were weighed, egg samples were taken, weighed and counted, then eggs/each hapa were placed for hatching in 151 plastic jars, through which a gentle and continuous flow of water was maintained.

Reproductive performance parameters were measured as follows:

Egg number/female/wk = Egg number/hapa/wk

Fry number/female/wk = female number/hapa/wk Fry number/hapa/wk

$$
\begin{aligned}
& \text { Hatching } \%=\quad \begin{array}{c}
\text { Fry number/hapa/wk } \\
\text { Egg number/hapa/wk }
\end{array} \\
& \text { Spawned females } \%=\quad \frac{\text { Spawned females number/hapa/wk } \times 100}{\text { Total females number }} \\
& \text { Number of spawning/fish/period }=\frac{(\text { Spawned female No/wk }) \times(\text { No of wk })}{\text { Total females number }} \\
& \text { Egg weight, g/fish }=\quad \frac{\text { Egg weight, g/hapa/wk }}{\text { Females No./hapa } / w k}
\end{aligned}
$$

The analysis of variance and LSD range test were used to compare treatment means. Data were analysed using statgraphic package software (SPSS, 1997). Level of significant was 0.05.

\section{RESULTS AND DISCUSSIONS:}

Table (2) showed the averages of water temperature and other water quality parameters, dissolved oxygen (DO) and water $\mathrm{pH}$, during the experimental period are 28.8, 5.7 and 8.2 respectively. All water quality parameters were within the suitable ranges for tilapia growth and reproduction as reported by Mironova (1977); Pompa and Lovshin (1996); Ambali (1990); Watanabe et al. (1992); Bevis (1994); Siddiqui et al. (1997); Siddiqui et al. (1998) and Ali (2001).

Reproductive performance parameters of Nile tilapia (Oreochromis niloticus) broodstock as affected by dietary Garlic level is shown in Table (3) As shown in this Table the reproductive performance parameters including spawned females number (No)/hapa/week (wk), eggs No/hapa/wk, eggs No/female/wk, fries No/hapa/wk, fries No/female/wk, hatching \%, No of spawning/fish/ experimental period, eggs weight, g/hapa/wk, eggs weight, $\mathrm{g} /$ fish/wk and relative fecundity were improved significantly $(\mathrm{P} \leq 0.05)$ with the diets containing Garlic $(0.5$ or $1.0 \%)$. However, there was insignificant improvement due to dietary Garlic level on the hatching \%. Garlic addition

Fayoum J. Agric. Res. \& Dev., Vol.24, No.2, July, 2010 
EFFECT OF GARLIC AS A FEED ADDITIVE ON REPRODUCTIVE.. 211

increased spawned females number/hapa/wk by about 158 and $162 \%$, eggs number/fish/wk by about 123 and 122\%, fry number/fish/wk about 128 and $126 \%$, eggs weight/fish/wk about 119 and $123 \%$ and relative fecundity about 123 and $122 \%$ for 0.5 and $1.0 \%$ dietary Garlic levels, respectively.

Table (2). Water quality parameters recorded in earthen pond

\begin{tabular}{|l|c|c|c|c|c|c|}
\hline \multirow{2}{*}{ Weeks } & \multicolumn{2}{|c|}{ Temperature, C } & \multicolumn{2}{c|}{$\mathbf{O}_{2}, \mathbf{m g} / \mathbf{L}$} & \multicolumn{2}{c|}{ pH } \\
\cline { 2 - 7 } & Min. & Max. & Min. & Max. & Min. & Max. \\
\hline \hline $21 / 6$ & 25 & 30 & 5.2 & 6.3 & 8.0 & 8.3 \\
$28 / 6$ & 26 & 31 & 5.1 & 6.2 & 8.2 & 8.3 \\
$5 / 7$ & 27 & 32 & 5.3 & 6.3 & 8.1 & 8.2 \\
$12 / 7$ & 27 & 33 & 5.0 & 6.4 & 8.1 & 8.1 \\
$19 / 7$ & 27 & 32 & 5.2 & 6.5 & 8.1 & 8.3 \\
$26 / 7$ & 27 & 32 & 5.0 & 6.2 & 8.0 & 8.1 \\
$2 / 8$ & 27 & 31 & 5.1 & 6.1 & 8.0 & 8.2 \\
$9 / 8$ & 26 & 31 & 4.9 & 6.4 & 8.3 & 8.1 \\
$16 / 8$ & 25 & 30 & 5.0 & 6.3 & 8.2 & 8.1 \\
\hline Average* & 26.3 & 31.3 & 5.1 & 6.3 & 8.1 & 8.2 \\
\hline
\end{tabular}

* Allover the experimental period

Table (3). Reproductive performance parameters of Nile tilapia broodstock as affected by dietary Garlic level.

\begin{tabular}{|c|c|c|c|c|}
\hline \multirow{2}{*}{ Parameters } & \multicolumn{3}{|c|}{ Garlic levels, \% } & \multirow{2}{*}{ SED } \\
\hline & 0.0 & 0.5 & 1.0 & \\
\hline Spawned females number/hapa/wk & $12.75^{\mathrm{b}}$ & $32.88^{\mathrm{a}}$ & $33.38^{\mathrm{a}}$ & 3.123 \\
\hline Spawned female \% & $8.50^{\mathrm{b}}$ & $21.92^{\mathrm{a}}$ & $22.25^{\mathrm{a}}$ & 2.082 \\
\hline Egg No/hapa/wk. & $11,355.64^{\mathrm{b}}$ & $25,485.49^{\mathrm{a}}$ & $25,205.08^{\mathrm{a}}$ & 2107.1 \\
\hline $\mathrm{Egg} \mathrm{No} /$ fish/wk. & $75.70^{\mathrm{b}}$ & $169^{\mathrm{a}}$ & $168^{\mathrm{a}}$ & 14.05 \\
\hline Fry No/hapa/wk. & $10422.21^{\mathrm{b}}$ & $23803.45^{\mathrm{a}}$ & $23503.74^{\mathrm{a}}$ & 2050.6 \\
\hline Fry No/ fish/wk. & $69.48^{\mathrm{b}}$ & $158.69^{\mathrm{a}}$ & $156.69^{\mathrm{a}}$ & 13.67 \\
\hline Hatching \% & 91.78 & 93.40 & 93.25 & 0.846 \\
\hline No of spawning/ fish/period ${ }^{1}$. & $0.68^{\mathrm{b}}$ & $1.75^{\mathrm{a}}$ & $1.78^{\mathrm{a}}$ & 0.092 \\
\hline Eggs weight/hapa/wk, g. & $100.88^{\mathrm{b}}$ & $220.29^{\mathrm{a}}$ & $225.66^{\mathrm{a}}$ & 16.567 \\
\hline Eggs weight/ fish/wk, g. & $0.67^{\mathrm{b}}$ & $1.47^{\mathrm{a}}$ & $1.50^{\mathrm{a}}$ & 0.110 \\
\hline Relative fecundity & $2.53^{\mathrm{b}}$ & $5.64^{\mathrm{a}}$ & $5.61^{\mathrm{a}}$ & 0.551 \\
\hline
\end{tabular}

Average in the same row having different superscripts ( $a, b$ and $c$ ) differ significantly $\mathrm{P} \leq 0.05$ 1 , Period $=8$ weeks.

2 , Relative fecundity $=$ total spawned eggs $/($ mean weight of female $\times$ total number of female per hapa)

Female No/hapa $=150$ female

However, there is no information in the literature showing the effect of Garlic as a feed additive on productive or reproductive performance of fish. It has been established that; Garlic has an influence on the intestinal digestive enzymes and a biological activity of brush border membrane of intestinal tract of rats (Gupta et al., 1998), it has a positive effect on growth performance of hamsters (Liu et al., 1997), pigs (Jost, 1997) and broilers (El-Nahla, 1983; Qureshi et al., 1983; El- Nawawy, 1991; Horton et al., 1991 and El-Afify, 1997), it has an antioxidant effect and it affected lipid metabolism in hamsters (Liu et al., 1997) and it has a positive effect on carbohydrate metabolism in rats

Fayoum J. Agric. Res. \& Dev., Vol.24, No.2, July, 2010 
(Ahmed and Sharma (1997); it has an antifungal effect against fungi isolated from cow and poultry feedstuffs of Egyptian origin (Mohawed $\boldsymbol{e t}$ al., 1996) and an antimicrobial effect (Abdou et al., 1973; Kiminoto et al., 1978; Srivastava et al., 1984; Shashikanth et al., 1986 a, b and El-Afify, 1997). Also, El-Afify (1997) found that it improved chick immunity and resistance for disease; regarding its effect on reproductive performance, El-Emary (1993) reported that chickens lay more eggs when Garlic is mixed with their food. Consequently the results obtained herein lead us to believe that dietary Garlic supplementation provide fish with effective substances which increased fish vitality, immunity and improved feed digestion, absorption and metabolic processes. And this was reflected directly and indirectly on improvement of their reproductive performance. Where, Garlic effects may help broodfish to recovery faster after they spawned and become ready to spawn again, accordingly they could produce several batches, furthermore, it improve egg and sperm quality. Shepherd and Bromage (1995) indicated that the elements which control gonadal function are as follow; In response to changing conditions in both the internal and external environments due to salinity, light, temperatures, rainfall, food and photoperiod, the hypothalamus secretes releasing hormones, where they control the activity of specific gonadotropic cells in the pituitary gland. In turn these cells secrete gonadotropic hormones, which pass in the blood to the gonads of the fish where they control all structural and functional changes in the testes and ovary. The results obtained herein lead us to believe that dietary Garlic supplementation provide fish with effective substances which affected on hypothalamus and/or metabolic processes. And this is reflected on improvement of their reproductive performance.

Growth performance and efficiency of feed utilization:

Growth performance and efficiency of feed utilization throughout the experimental period are shown in Table (4).

As shown in this Table, the increase in broodfish body weight was limited due to the use of low feeding level, beside the fish were converting the bulk of their ingested energy into gonad development to a greater extent than that for flesh. Growth rates were similar for the tested diets. These results in agreement with those obtained by Ali (2001) when he used the same rate of feeding with Nile tilapia broodstock.

The total amounts of feed consumed tended to be equal among the tested diets according to the equality of brood body weight throughout the experimental period, where feed was fed to fish according to periodical weighing of fish, which was equal $0.5 \%$ of fish body weight. While feed conversion ratio as calculated as $\mathrm{g}$ feed required to produce 1000 fry as well as its related costs, in diets supplemented with Garlic $(0.5$ or $1.0 \%)$ were the best when compared with the control diet.

It could be concluded that tilapia diets supplemented with Garlic $(0.5$, or $1.0 \%)$ had a positive effect on their reproductive performance and feed utilization. Also, it had positive effect in reducing the feeding costs for tilapia seed production. Garlic supplementation decreased the feed cost/1000 fry about 55 and $53 \%$ for 0.5 and $1.0 \%$ Garlic levels, respectively compared with the control diet $(0.0 \%$ Garlic). The comparison between Garlic levels may suggest the use of $0.5 \%$ Garlic level. Also, further studies are needed with Garlic on fish to explain its mode of action on reproductive performance of fish and to evaluate another levels from Garlic to determine the most effective level.

Fayoum J. Agric. Res. \& Dev., Vol.24, No.2, July, 2010 
EFFECT OF GARLIC AS A FEED ADDITIVE ON REPRODUCTIVE.. 213

Table (4). Growth performance and feed utilization efficiency of Nile tilapia broodstock as affected by dietary Garlic level.

\begin{tabular}{|c|c|c|c|c|}
\hline \multirow{2}{*}{ Item } & \multicolumn{3}{|c|}{ Garlic levels, \% } & \multirow{2}{*}{ SED } \\
\hline & 0.0 & 0.5 & 1.0 & \\
\hline Initial mean weight, $g$ & 239.50 & 241.00 & 239.50 & 2.380 \\
\hline Final mean weight, $g$ & 285.00 & 287.00 & 283.50 & 4.916 \\
\hline || Total gain, $\mathrm{g}$ & 45.50 & 46.00 & 44.00 & 2.972 \\
\hline Daily gain, $g$ & 0.73 & 0.74 & 0.71 & 0.048 \\
\hline SGR, \% & 0.28 & 0.28 & 0.27 & 0.015 \\
\hline Total feed used, g/fish & 81.30 & 81.84 & 81.07 & 1.105 \\
\hline Total feed used, $\mathrm{kg} / \mathrm{hapa}$ & 16.26 & 16.37 & 16.21 & 0.245 \\
\hline Feed required to produced 1000 fry, $\mathrm{kg}^{*}$ & 0.195 & 0.086 & 0.086 & 0.039 \\
\hline The cost of feed, LE/1000 fry** & 0.585 & 0.262 & 0.267 & 0.048 \\
\hline
\end{tabular}

Average in the same row having different superscripts differ significantly $\mathrm{P} \leq 0.05$.

* 1000 (Total feed used, kg/hapa/ Number of fry produced per hapa/total period).

** The price of $1 \mathrm{~kg}$ from $\mathrm{D}_{1}, \mathrm{D}_{2}$, and $\mathrm{D}_{3}$ was 3.0, 3.05 and $3.10 \mathrm{LE}$, respectively.

\section{REFERENCES}

Abd El-Maksoud, A.M.S., Aboul-Fotouh, G.E., Allam, S.M. and Abou Zied, R.M. (1998a). The Effect of Feeding Diets Containing Chamomile Flowers on Growth, Survival and Feed Utilization of Nile Tilapia (Oreochromis niloticus) Fingerlings. Fayoum J. Agric., Res \& Dev., 12: 181- 192.

Abd El-Maksoud, A.M.S., Allam, S.M., Aboul-Fotouh, G.E. and Abou Zied, R.M. (1998b). Evaluation of Nigella Seeds (Nigella Sativa L.) as a Feed Additive In Diets of Nile Tilapia (Oreochromis Niloticus). Fayoum J. Agric. Res \& Dev., 12: 170-181.

Abd El-Maksoud, A.M.S., Aboul-Fotouh, G.E., Allam, S.M. and Abou Zied, R.M. (1999). Effect of Marjoram Leaves (Majorana Hortensis L.) as a Feed Additive on The Performance of Nile Tilapia (Oreochromis niloticus) Fingerlings. Egyption J. Nutr. and Feeds, 2: $39-47$.

Abdou, I.A., Abou Zied, A.A. and El-Sherbeeny M.R. (1973). Antimicrobial activities of Allium satvium, Allium cepa on bacteria. Nutr. Abst. Rev. 43: 7.

Ahmed, R.S and Sharma, S.B. (1997). Biochemical studies on combined effects of garlic (Allium sativum Linn) and ginger (Zingiber officinale Rosc) in albino rats. Indian J. Exp. Biol., 35 (8): 841- 843.

Ali, A.A.A. (2001). The effect of some nutritional treatments on fecundity, sex reversal and productive performance of Nile tilapia. Ph.D. Thesis, Fac. Agric., El-Fayoum, Cairo Univ. ARE.

Ambali, A.J.D. (1990). Effect of hapa size on conditioning of broodstock, (Oreochromis niloticus) in fertilized earthen ponds. M.Sc. Thesis. Asian Ins. Tech.

Bevis, R. (1994). The effect of artificial nests on reproductive performance in the Nile tilapia (Oreochromis niloticus, L.) spawned in net hapas. M. Sc. Thesis, Asian Inst. Tech.

Day, A. and Samanto, A.R. (1993). Effect of feeding garlic as growth promoter in broiler. Indian J. of Anim. Health, 23: 1

El-Afify, S.F. (1997). Nutritional studies on onion and Garlic supplement to poultry feed. Ph.D Thesis, Fac. Agric. Ain Shams Univ. ARE.

El-Emary, N.A. (1993). Egyptian Medicinal Plants: An Overview I, Assiut J. Env. Studies, Overview Series, No 2, 18-19.

Fayoum J. Agric. Res. \& Dev., Vol.24, No.2, July, 2010 
El-Nahla, A.M.M. (1983). Effect of some feed additives on blood constituents and growth rate in chickens. M.Sc. Thesis Fac. Vet. Med., Cairo Univ., Egypt.

El-Nawawy, G.H. (1991). Some of non conventional ingredients in broiler ration. M.Sc. Thesis, Anim. Prod. Dept. Fac. Agric. Ain-Shms Univ. ARE.

Gupta, A., Sandhu, R.S. and Gupta, A. (1998). Effect of garlic agglutinin and garlic extracts on the rat jejunum. Nutr., Res., 18 (5): 841-850.

Horton, G.M.I., Fennell, M.J. and Prasad B.M. (1991). Effect of dietary garlic (Allium Sativum) on performance, carcass composition and blood chemistry changes in broiler chicken. Can. J. Anim. Sci. 71: 939-942.

Jalabert, B. and Zohar, Y. (1982). Reproductive physiology in cichlid fishes, with particular reference to Tilapia and Sarotherodon. p. 129-140. In: Pullin. R.S.V., Lowe-McConnell, R.H. (Eds.), The biology and culture of tilapias, ICLARM Conf. Proc. $7^{\text {th }}$, Manila, Philippines, $432 \mathrm{pp}$.

Jost, M. (1997). Use of garlic powder in the feed of rearing piglets. Revue, Suisse, d'Agriculture. 29 (1): 35-38.

Kiminoto, Y., Nishemura, S. and Kimoro, T. (1978). Studies on the biological active component of garlic. Isolation and bacterostaic effect of scordinin and decomposition product. Chem. Abst., Bioch. Sec. 88: 8.

Little, D.C., Macintosh, D.J. and Edwards, P. (1993). Improving spawning synchrony in the Nile tilapia, Oreochromis niloticus (L.). Aquacult., Fish., Manag., 24: 399-405.

Little, D.C., Turner, WA. and Bhujel, R.C. (1997). Commercialization of a hatchery process to produce MT-treated Nile tilapia in Thailand. pp. 108118. In: Alston, D.E. Green, B.W., Clifford, H.C. (Ms.), IV Symp., Aquaculture in Central America: Focusing on shrimp and tilapia, 22-24 April, Tegucigalpa, Honduras, Asociacion Nacional de Acuicultores de Honduras and the Latin American Chapter of the World Aquaculture Society, $237 \mathrm{pp}$.

Liu, Y., Shieh, M., Cheng, H., Shieh, M., Liu, Y.L., Shieh, M.S., Cheng, H.H. and Shieh, M.J. (1997). The influences of garlic on growth, antioxidative effect, and lipid metabolism in hamsters. Nutl., Sci., J., 22 (4): 385- 398.

Macintosh, D.L. and Little, D.C. (1995). Nile tilapia (Oreochromis niloticus). In: Bromage, N.R., Roberts, R.J. (Eds.) Broodstock Management and Egg and Larval Quality. Chap. 12, Blackwell, Cambridge, MA, USA, pp. 227-320.

Mires, D. (1982). A study of the problems of the mass production of hybrid tilapia fry, p. 317-329. In: Pullin. R.S.V., Lowe-McConnell, R.H. (Eds.), The biology and culture of tilapias. ICLARM Conf., Proc., Manila, Philippines, $432 \mathrm{pp}$

Mironova, N.V. (1977). Energy expenditure on egg production in young Tilapia mossambica and the influence of maintenance conditions on their reproductive intensity. J. lchthyol. 17: 627-633.

Mohawed, S.M., Moharram, A.M., Abdel, Hafez, S.II and Gherbawy, Y.A.M. (1996). Effects of garlic extract and some organic compounds on feedstuffs fungi in Qena, Egypt. Egyptian, J, Microbiology. 31 (1): 129- 138.

Omar, E.A. (1984). Effect of type of feed, level and frequency of feeding on growth performance and feed utilization by mirror carp (Cyprinus carpio, L). $\mathrm{Ph}$ D dissertation, George-August Univ. Gottingen, Germany.

Popma, T.J. and Lovshin, L.L. (1996). Worldwide prospects for commercial production of tilapia. Research and development No. 41, Dept., Fish., \& Allied Aquacult., Auburn Univ., AL, USA, 23 pp.

Fayoum J. Agric. Res. \& Dev., Vol.24, No.2, July, 2010 
EFFECT OF GARLIC AS A FEED ADDITIVE ON REPRODUCTIVE.. 215

Qureshi, A., Din, Z.Z., Abuirmeileh, N. Burger, W.C., Ahmed, Y. and Elson, C.E. (1983). Suppression of avian hepatic metabolism by solvent extracts garlic: impact on serum lipids. J. Nutr. 113: 1746-1755.

Shashikanth, K.N., Basappa, S.C. and Murthy, S. (1986a). Allicin concentration in the gut of rats and its influence on the microflora. Nutr. Abst. Rev., 57: 2.

Shashikanth, K.N., Basappa, S.C. and Murthy, S. (1986b). Effect of feeding raw and boiled garlic extracts on the growth, fecal microflora and serum proteins on Albino rats. Nutr. Reports Inter., February 33 (2): 313-319.

Shepherd, C.J. and Bromage, N.R. (1995). Intensive fish farming. Oxford London, Edinburgh. pp 103-153.

Siddiqui, A.Q., Al-Hafedh Y.S. and Ali S.A. (1998). Effect of dietary protein level on the reproductive performance of Nile tilapia, Oreochromis niloticus L. Aquaculture Res. 29: 349-358.

Siddiqui, A.Q., Al-Harbi A.H. and Al-Hafedh Y.S. (1997). Effects of food supply on size at first maturity, fecundity and growth of hybrid tilapia (Oreochromis niloticus $\times$ O. aureus) in outdoor concrete tanks in Saudi Arabia. Aquaculture Res. 28: 341-349.

Springate, J., Bromage, N. (1984). Egg size and number - it's a 'trade-off'. Fish Farmer 7 (4): 14-15.

SPSS. (1997). Statistical Package For Social Science (for Windows). Release 8.0 Copyright (C), SPSS Inc., Chicago, USA.

Srivastava, K.C., Pereva, A.D. and Aridakia, H.D. (1984). Bacteriostatic effect of garlic sapa on negative pathogenic bacteria (an in vitro study). Horticultural Abst. 54: 104.

Watanabe, W.O., Smith S.T., Wicklund R.I. and Ola B.L. (1992). Hatchery production of Florida red tilapia seed in brakishwater tanks under natural mouthbrooding and clutch removal methods. Aquaculture, 102 (1-2): 77-88.

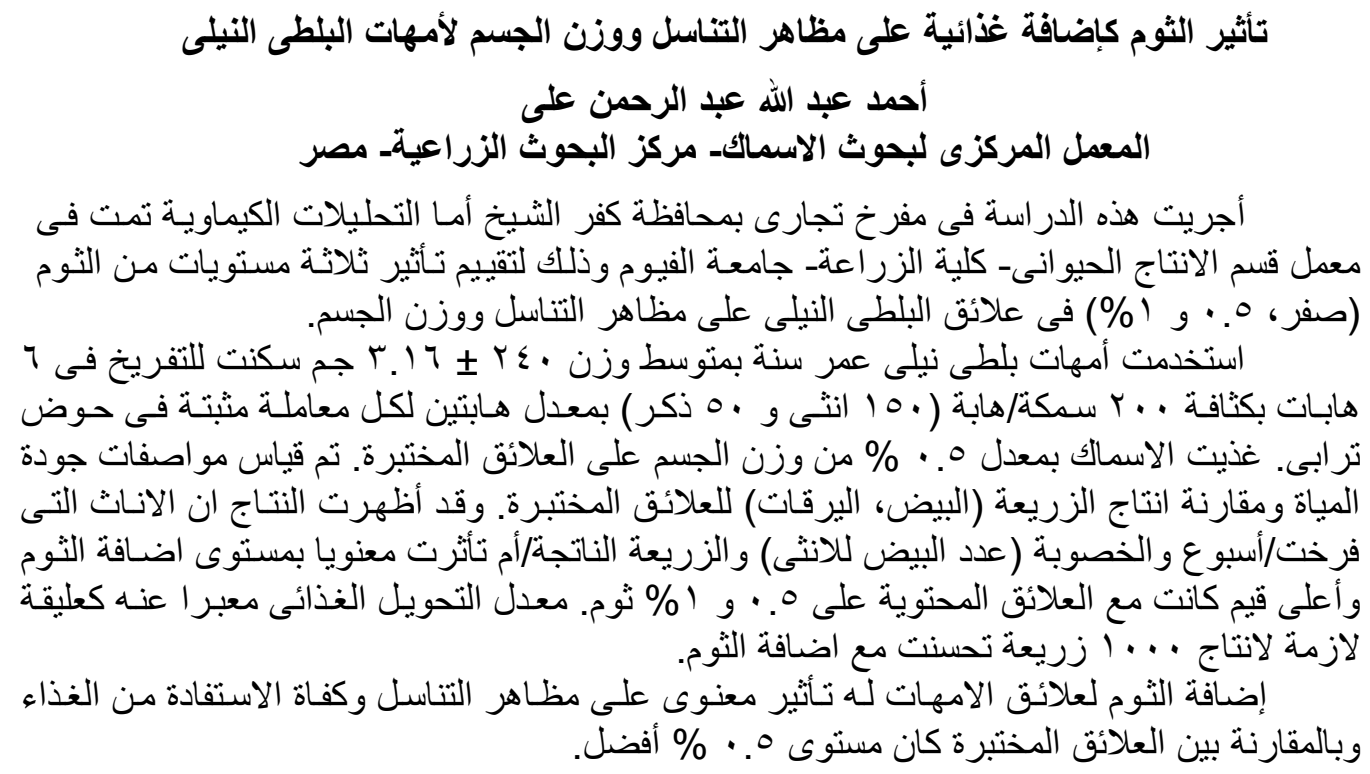

Fayoum J. Agric. Res. \& Dev., Vol.24, No.2, July, 2010 